\title{
Efektifitas modifikasi permainan tradisional dalam pengembangan physical literacy anak taman kanak-kanak
}

\author{
Uray Gustian*, Eka Supriatna, Edi Purnomo \\ Program Studi Pendidikan Kepelatihan Olahraga, Fakultas Keguruan dan Ilmu Pendidikan, \\ Universitas Tanjungpura. Jalan Prof. Dr. Hadari Nawawi, Pontianak, 78124, Indonesia. \\ * Corresponding Author. E-mail: uray.gustian@fkip.untan.ac.id
}

Received: 29 November 2018; Revised: 11 February 2019; Accepted: 21 February 2019

\begin{abstract}
Abstrak
Mengembangkan perilaku anak taman kanak-kanak untuk aktif dalam bergerak merupakan aspek penting dalam konteks perkembangan manusia. Tujuannya adalah agar anak memiliki keterampilan, pengetahuan, motivasi, dan kepercayaan diri melakukan aktivitas gerak atau yang dikenal dengan physical literacy (PL). Akan tetapi, seiring dengan pengaruh televisi dan gadget menyebabkan anak menjadi kurang dalam melakukan gerak sehingga banyak anak yang mengidap berbagai penyakit degeneratif dan kurang terampil dalam melakukan aktivitas gerak. Untuk itu, diperlukan suatu usaha untuk menstimulus anak selalu aktif melakukan gerak. Rancangan percobaan yang digunakan adalah one-group pretest-postest design. Percobaan dilakukan dengan mengimplementasikan permainan tradisional yang dimodifikasi pada pembelajaran taman kanak-kanak. Permainan tradisional yang digunakan terdiri atas tujuh permainan yaitu lempar kaleng, engklek, lempar telur penyu, sumpitan, balap balon, estafet kelereng, dan bakiak. Hasil percobaan menunjukan telah terjadi peningkatan PL ketika permainan tradisional digunakan sebagai aktivitas pembelajaran. Adanya peningkatan PL disebabkan permainan tradisional telah dapat menstimulus anak untuk aktif melakukan aktivitas gerak dan efektif dalam mengembangan PL anak taman kanak-kanak.
\end{abstract}

Kata Kunci: permainan tradisional, physical literacy, anak Taman Kanak-Kanak

\section{Effectiveness of traditional game modified to develop a physical literacy in preschool student}

\begin{abstract}
Developing preschool students to physicaly active is an important aspect in the context of human development. The aim is so that preschool students have the skills, knowledge, motivation, and selfconfidence to carry out motion activities or what is known as physical literacy $(P L)$. However, along with the influence of television and gadgets causing preschool students to become less engaged in movement, many preschool students suffer from various degenerative diseases and are less skilled in doing motion activities. For this reason, an effort is needed to stimulate preschool students to always be active. The experimental design was used one-group pretest posttest design. The experiment was carried out by implementing a modified traditional games on Kindergarten learning. The traditional games used consisted of seven games, namely lempar kaleng, engklek, lempar telur penyu, sumpitan, balap balon, estafet kelereng, dan bakiak. The experimental results show that there has been an increase in PL when traditional games are used as learning activities. The existence of an increase in PL due to traditional games has been able to stimulate children to actively engage in motion activities and be effective in developing PL for kindergarten children.
\end{abstract}

Keywords: traditional games, physical literacy, preschool student.

How to Cite: Gustian, U., Supriatna, E., \& Purnomo, E. (2019). Efektifitas modifikasi permainan tradisional dalam pengembangan physical literacy anak taman kanak-kanak. Jurnal Keolahragaan, 7(1), 23-33. doi:https://doi.org/10.21831/jk.v7i1.22166

https://doi.org/10.21831/jk.v7i1.22166

\section{PENDAHULUAN}

Physical literacy (PL) merupakan kemampuan untuk melakukan gerak, kepercayaan terhadap kemampuan dirinya, menerapkan pola hidup sehat dengan menerapkan gaya hidup aktif, dan memiliki keterampilan gerak dasar yang 
baik. Dalam konteks pendidikan untuk Taman kanak-kanak (TK), PL mengacu kepada pengembangan keterampilan gerak dasar dan dasar gerak olahraga yang dapat mendorong anak untuk memiliki kepercayaan terhadap kemampuan dirinya, menerapkan gaya hidup sehat dengan gaya hidup aktif, dan memiliki keterampilan gerak. (Higgs et al., 2008, p. 6) dan mendorong pencapaian literasi anak secara keseluruhan (Daggett, 2010, p. 42).

PL merupakan hal yang fundamental bagi anak karena usia kanak-kanak merupakan masa anak untuk aktif melakukan gerak dan aktivitas gerak, yang pada umumnya terbentuk di rentang usia 2-5 tahun (Taylor, Williams, Farmer, \& Taylor, 2013, pp. 5-6). Usia TK merupakan periode penting dalam perkembangan anak, karena pada masa ini keterampilan gerak dasar, sosial dan kognitif terbentuk (Kirk \& Rhodes, 2011, p. 210). Selain itu juga, banyak manfaat yang dapat diperoleh oleh anak ketika aktif dalam melakukan gerak diantaranya menjaga kesehatan, khususnya dalam pencegahan obesitas pada anak (Williams et al., 2008, p. 1421), memperoleh manfaat dalam perkembangan kognitif dan performa akademik (Haapala, 2013, p. 61), meningkatan kemampuan kognitif dan peningkatan pencapaian akademik anak (Fedewa \& Ahn, 2011, p. 532), mengembangkan keterampilan psikomotorik dan memberikan manfaat psikologis melalui pengembangan tanggung jawab pribadi dan sosial dan perilaku sosial yang tepat (Liu, Karp, \& Davis, 2010, p. 38).

Pentingnya PL dan besarnya manfaat yang diperoleh anak ketika melakukan gerak seharusnya menjadi perhatian serius bagi orangtua untuk mendorong anak agar selalu aktif dalam melakukan dan mengembangkan keterampilan geraknya. Selain itu juga, peran dari pendidik juga sangat diperlukan dalam mendorong anak untuk aktif melakukan gerak agar dapat tumbuh dan berkembang dengan sehat dan kuat, seperti diketahui $100 \%$ masa depan berada ditangan anak-anak yang ada pada saat ini.

Pada era sekarang ini tidak jarang ditemukan anak yang mengalami berbagai panyakit degeneratif yang diakibatkan kurangnya dalam melakukan aktivitas gerak (inactivity). Akibatnya adalah anak berada pada risiko yang lebih besar mengidap penyakit berbahaya yaitu noncommunicable diseases (NCDs) dan gangguan kesehatan umum lainnya seperti obesitas, serangan jantung, hypertensi, kanker, dan diabetes (World Health Organization, 2011, p. 6) dan mengalami keterlambatan dalam perkembangan sosial, emosional, dan kognitif yang terjadi sepanjang hidupnya (Kohl et al., 2012, p. 395). Selain itu juga, anak yang memiliki keterampilan gerak rendah menunjukan sikap kurang aktif dalam belajar dibanding anak yang memiliki keterampilan gerak baik (Williams et al., 2008, p. 1422).

Anak kurang aktif dalam melakukan aktivitas gerak disebabkan lebih banyak menghabiskan waktunya untuk menonton televisi atau bermain gadget. Pada saat ini telah terjadi peningkatan sebanyak $30 \%$ anak yang menghabiskan waktunya lebih dari dua jam sehari untuk menonton televisi dimana anak hanya boleh menonton televisi maksimum dua jam perhari. Dampak buruk yang ditimbulkan adalah terjadinya penurunan dalam kemampuan kosa kata dan keterampilan matematika, anak sulit untuk memusatkan perhatian, dan keterlambatan dalam keterampilan gerak (Pagani, Fitzpatrick, \& Barnett, 2013, pp. 2-4).

Berdasarkan hal tersebut tentunya diperlukan suatu usaha untuk mendorong anak agar selalu aktif dalam melakukan aktivitas gerak. Salah satunya adalah dengan pembiasaan dalam melakukan gerak yang dilakukan melalui pengoptimalan pembelajaran gerak di TK. Pentingnya pembentukan perilaku hidup aktif pada anak TK disebabkan masa kanak-kanak merupakan masa golden age yang akan mempengaruhi kualitas perkembangan tahap selanjutnya.

TK merupakan salah satu lembaga formal yang menyelenggarakan pendidikan untuk anak usia dini. Pendidikan TK dilakukan melalui pemberian stimulus untuk mengoptimalkan seluruh potensi yang dimiliki anak agar terbentuk perilaku dan kemampuan dasar sesuai dengan tahap perkembangan anak (Direktorat Pembinaan Pendidikan Anak Usia Dini, 2011, p. 4). Seiring dengan perkembangan ilmu pengetahuan, sasaran (ouput) dari pembelajaran gerak mengarah kepada mendorong anak memiliki motivasi dan kemampuan untuk memahami, berkomunikasi, menerapkan pengetahuan, dan menganalisis gerakan secara kritis dengan berbagai cara dan menunjukan fleksiblitas gerak dengan percaya diri, kompeten, dan kreatif (Butler \& Griffin, 2010, p. 35).

Permasalahan yang terjadi dalam konteks pembelajaran gerak di TK adalah kurangnya pemahaman dari guru terhadap aktivitas gerak dan guru kesulitan mengembangkan bentuk model aktivitas jasmani yang sesuai untuk digunakan dalam kegiatan pembelajaran (Gustian \& Tomoliyus, 2015, p. 246) serta tidak ada 
perencanaan dan keterbatasan model dan contoh (Robinson \& Goodway, 2009, p. 540).

Berdasarkan pada permasalahan tersebut, Perlunya usaha untuk menstimulus keterampilan gerak dasar dan kepercayaan diri anak sehingga anak memiliki motivasi dan kemampuan untuk memahami aktivitas gerak yang dilakukan, memiliki kepercayaan diri terhadap kemampuan geraknya, menerapkan pola hidup aktif, dan memiliki kemampuan gerak yang baik. Dalam penelitian ini memfokuskan pada mendorong anak agar mau, mampu, dan senang dalam melakukan aktivitas gerak

Permainan yang digunakan yaitu permainan tradisional yang telah dimodifikasi. Dasar pemilihan olahraga tradisional karena memiliki dampak positif terhadap perkembangan psikis, fisik, dan membentuk karakter anak. Hal ini disebabkan pada permainan tradisional anakanak diajarkan untuk jujur dan melatih gerak psikomotor (Yudiwinata \& Handoyo, 2014, p. 4), meningkatkan kemampuan berbahasa dan sosial emosional anak (Darminiasih, Marhaeni, \& Sutama, 2014, p. 9), melatih anak untuk memanajemen konflik, dan memecahkan masalah yang hadapinya (Kurniati, 2016, p. 12).

Penggunaan permainan tradisional sebagai media pembelajaran aktivitas gerak anak dapat dengan mudah menarik perhatian anak karena permainan berasal dari aktivitas sehari-hari di lingkungan tempat tinggal sehingga anak tidak merasa asing pada permainan tersebut. Selain menjadi media permainan aktivitas gerak pada anak, penggunaan permainan tradisional juga dapat menjaga dan mengembangkan kearifan lokal. Berdasarkan pemaparan tersebut maka permainan tradisional sangat tepat digunakan sebagai alternatif dalam pengembangan PL anak.

\section{METODE}

Penelitian dilakukan dengan mengimplementasikan permainan tradisional dalam pembelajaran anak TK. Adapun permainan tradisional yang digunakan dalam pembelajaran untuk mengembangkan PL anak TK terdiri atas tujuh permainan tradisional yaitu permainan lempar kaleng, permainan engklek, permainan lempar telur penyu, sumpitan, balap balon, estafet kelereng, dan bakiak. Prosedur pelaksanaan aktivitas pembelajaran dapat dilakukan dalam dua kali pertemuan dengan alokasi waktu masing-masing sekitar 60 dan 75 menit. Pertemuan pertama melakukan permainan sumpitan, lempar telur penyu, dan lempar kaleng. Pertemuan kedua melakukan permainan engklek, bakiak, balap balon, dan estafet kelereng. Dalam satu kali pertemuan dibagi ke dalam tiga tahapan yaitu tahap pendahuluan, tahap inti dan tahap penutupan.

Desain uji coba menggunakan metode eksperimen dengan desain single one shot case study dengan jumlah partisipan sebanyak 150 anak TK yang tersebar di lima TK. Indikator penilaian dilihat dari kemudahan guru dalam menterjemahkan buku literatur dan mengimplementasikan model aktivitas pembelajaran serta kemudahan anak dalam melakukan aktivitas pembelajaran. Guru yang bersangkutan diminta pendapatnya mengenai penggunaan model pembelajaran pada saat mengimplementasikan model pembelajaran yang dikembangkan. Kemudahan anak dalam melakukan permainan dilihat dari anak mau, mampu, dan senang dalam melakukan.

Penilaian dilakukan dengan teknik unjuk kerja, observasi (pengamatan) dan diperkuat dengan menggunakan teknik wawancara. Penilaian mencakup aspek kognitif/pengetahuan, aspek motorik/skill dan aspek afektif/sikap. Penilaian dilakukan oleh guru yang bersangkutan. Anak diminta untuk melakukan kegiatan yang terdapat pada model aktivitas pembelajaran berbasis permainan tradisional selanjutnya dinilai oleh guru. Guru mengamati segala aktivitas yang dilakukan oleh Anak.

Instrumen untuk mengukur pencapaian hasil belajar anak mengunakan rubrik penilaian dan tingkat kesenangan anak dalam melakukan menggunakan instrumen wawancara. Indikator penilaian yang terdapat pada rubrik penilaian mencakup pemahaman (bisa dan mampu melakukan), proses gerak (unjuk kerja), perilaku anak (kesenangan dalam melakukan). Penilaian oleh guru dilakukan sesuai dengan pedoman penilaian yang terdapat pada Tabel 1 . Selanjutnya data yang diperoleh dianalisis menggunakan pendekatan analisis deskriptif dan analisis statistik.

Tabel 1. Pedoman Penilaian Unjuk Kerja Anak

\begin{tabular}{cl}
\hline Nilai & \multicolumn{1}{c}{ Kategori } \\
\hline 1 & Belum Berkembang \\
2 & Mulai Berkembang \\
3 & Berkembang sesuai harapan \\
4 & Berkembang sangat baik \\
\hline
\end{tabular}

\section{HASIL DAN PEMBAHASAN}

Bermain merupakan aktivitas yang melekat dalam diri anak khususnya anak usia TK. Anak lebih banyak melakukan aktivitasnya dengan bermain bahkan pembelajaran untuk anak dilakukan sambil bermain. Selain itu jgua 
manfaat yang diperoleh anak ketika bermain adalah anak dapat belajar mengenai kemampuan gerak yang ada pada tubuhnya (Gallahue \& Ozmun, 2006), mendorong anak untuk mengembangkan kreatifitas dan imajinasi, ketangkasan, fisik, kognitif, dan kekuatan (Ginsburg, 2007), mendorong perkembangan motorik, afektif, dan sosial (Kovar, 2004) dan melalui aktivitas bermain yang dilakukan melalui aktivitas permainan dapat mengembangkan keterampilan gerak fundamental anak (Gustian \& Hidasari, 2017). Untuk itu, diperlukan suatu media untuk menfasilitasi anak dalam bermain yaitu melalui permainan tradisional.

Permainan tradisional merupakan permainan yang berkembang di suatu daerah tertentu yang memiliki nilai-nilai budaya dan nilai kehidupan masyarakat yang diturunkan secara turun temurun (Kurniati, 2016) dan hasil budaya suatu masyarakat di suatu daerah atau wilayah (Permuseuman, 1998). Permainan tradisional yang berkembang dari hasil prakarya masyarakat dari penggalian nilai budaya yang diwariskan secara turun menurun. Permainan tradisional juga dipengaruhi oleh kultur dan kondisi lingkungan yang ada (Yudiwinata \& Handoyo, 2014). Hal ini yang menyebabkan setiap daerah memiliki permainan tradisional dengan cirinya masingmasing.

\section{Permainan Lempar Kaleng}

Permainan lempar kaleng merupakan permainan tradisional pada umumnya dilakukan dengan melempar kaleng yang telah disusun menggunakan sandal/batu/pecahan genteng. Permainan lempar kaleng yang digunakan dalam aktivitas pembelajaran yang permainan melempar potongan bambu menggunakan bola tenis. Anak akan melempar bambu yang telah disusun berbentuk pyramid dengan jarak sekitar 3 meter. Sebelum melempar anak harus melewati beberapa rintangan yaitu melompat, merangkak, berjalan diatas garis. Bambu dipotong berukuran tinggi sekitar $10 \mathrm{~cm}$ sebanyak 10 buah.

Tujuan permainan adalah untuk melatih kemampuan melempar, melompat, merangkak, dan berjalan di atas garis, mendorong anak untuk melakukan aktivitas gerak, melakukan aktivitas bola kearah bamboo, dan menumbuhkan kesenangan anak dalam melakukan aktivitas gerak. Adapun indikator keberhasilan yaitu anak dapat melemparkan bola, melompat, merangkak melewati gawang, dan berjalan melewati garis, dapat menjatuhkan semua bambu yang disusun meng- gunakan bola, dan gembira dalam melakukan permainan.

Permainan dilakukan dengan cara anak dibagi ke dalam tiga atau empat kelompok. Masing-masing kelompok membuat barisan berbanjar dan anak yang paling depan berada di belakang garis mulai. Setelah mendapat aba-aba dari guru masing-masing kelompok berlomba menjatuhkan sususan bambu menggunakan bola dengan dilempar. Akan tetapi sebelum melempar, anak-anak harus melewati rintangan yaitu melompat diatas tempat yang telah ditentukan, merangkak melewati gawang, dan berjalan diatas garis lurus. Kelompok yang terlebih dahulu menjatuhkan semua bambu dinyatakan sebagai pemenang.

Hasil penelitian pada permainan lempar kaleng sebagaimana disajikan pada Tabel 2 diperoleh hasil pertemuan pertama kemampuan melempar bola diperoleh nilai 392 (2.61) dan pertemuan II diperleh nilai 466 (3.11), kemampuan melompat anak pada pertemuan I diperoleh nilai 474 (3.16) dan 482 (3.21) pada pertemuan II, kemampuan merangkak pertemuan I diperoleh nilai 462 (3.08) dan 490 (3.27) pada pertemuan kedua, kemampuan berjalan di atas garis pertemuan I 488 (3.25) dan 421 (3.49) pada pertemuan II, keterampilan menjatuhkan bamboo pertemuan I 382 (2.55) dan 421 (2.81) pada pertemuan II, dan untuk kegembiraan 474 (3.16) dan 498 (3.32) serta secara keseluruhan permainan lempar kaleng diperoleh hasil 2672 (2.97) untuk pertemuan I dan 2880 (3.32) untuk pertemuan II. Berdasarkan pencapaian hasil belajar anak ketika melakukan permainan lempar kaleng menunjukan telah terjadi peningkatan terhadap kemampuan anak dalam melemparkan bola, melompat, merangkak, berjalan di atas garis, menjatuhkan bambu, dan kegembiraan anak serta secara keseluruhan telah terjadi peningkatan perolehan hasil antara pertemuan I dan pertemuan II untuk permainan lempar kaleng. Hal ini menunjukan telah terjadi peningkatan kemampuan PL yang termuat dalam permainan lempar kaleng yaitu dari mulai berkembang menjadi berkembang sesuai harapan.

Permainan Engklek

Permainan engklek merupakan permainan tradisional merupakan permainan tradisional yang biasa dilakukan oleh anak-anak dengan cara melakukan engklek dan lompa pada tempat yang ditentukan. Permainan engklek yang digunakan sebagai aktivitas pembelajaran yaitu permainan memindahkan bola tenis dari satu keranjang ke keranjang lainnya dengan melakukan engklek 
dan lompat pada posisi yang yang telah ditentukan secara bergantian terlebih dahulu. Dalam permainan ini benda yang dipindahkan adalah bola tenis.

Tujuan permainan untuk melatih kemampuan gerak dasar (gerak lokomotor), mendorong anak untuk memecahkan masalah sederhana, dan menumbuhkan kesenangan anak dalam melakukan aktivitas gerak. Indikator keberhasilan yaitu anak dapat melakukan aktivitas engklek dan lompat, dapat melewati rintangan yang diberikan dalam memindahkan bola, dan senang dalam melakukan aktivitas permainan.

Permainan dilakukan dengan cara guru menyiapkan dan menyusun peralatan yang akan diperlukan dalam permainan dan membuat garis pembatas garis start dan finish. Kemudian guru membagi anak menjadi ke dalam beberapa kelompok dengan jumlah anak untuk masingmasing kelompok berjumlah 5 orang atau menyesuaikan dengan jumlah anak (jumlah maksimal 4 kelompok). Sebelum memulai permainan guru menjelaskan pada anak mengenai permainan yang dilakukan yaitu permainan memindahkan bola dari keranjang yang satu ke keranjang yang lainnya dengan melewati rintangan yaitu melakukan engklek dan melompat. Setelah anak berhasil memindahkan bola selanjutnya anak kembali ke barisan melewati samping permainan dan dilanjutkan oleh anak berikutnya hingga semua bola berhasil dipindahkan. Jumlah engklek dan lompatan disesuaikan dengan kondisi lapangan dan kondisi anak. Ketika anak melakukan permainan guru mengamati dan mengawasi anak yang sedang melakukan permainan. Kelompok yang berhasil memindahkan bola terlebih dahulu dinyatakan sebagai pemenang.

Hasil penelitian pada permainan engklek yang disajikan pada Tabel 3 diperoleh hasil pertemuan pertama kemampuan melakukan engklek diperoleh nilai 467 (3.11) dan pertemuan II diperoleh nilai 472 (3.15), kesesuaian engklek pada pertemuan I diperoleh nilai 482 (3.21) dan 490 (3.26) pada pertemuan II, kemampuan merangkak pertemuan I diperoleh nilai 462 (3.08) dan 490 (3.27) pada pertemuan kedua, dan untuk kegembiraan 492 (3.28) dan 523 (3.49) serta secara keseluruhan permainan engklek diperoleh hasil 1441 (3.20) untuk pertemuan I dan 1485 (3.08) untuk pertemuan II. Berdasarkan pencapaian hasil belajar menunjukan telah terjadi peningkatan terhadap kemampuan anak dalam melakukan engklek, kesesuaian engklek dan kegembiraan anak serta secara keseluruhan telah terjadi peningkatan perolehan hasil antara pertemuan I dan pertemuan II untuk permainan lempar kaleng. Hal ini menunjukan secara perolehan hasil telah terjadi peningkatan PL pada permaian engklek.

\section{Permainan Lempar Telur Penyu}

Permainan telur penyu merupakan permainan tradisional masyarakat Kecamatan Paloh Kabupaten Sambas Kalimantan Barat yang dilakukan pada zaman dahulu ketika musim penyu bertelur. Permainan telur penyu dilakukan dengan melempar bola kasti/bola plastik ke arah target yang ditentukan yang berbentuk gambar penyu dimana gambar tersebut diberi lobang dan didalamnya diberikan jaring atau keranjang. Anak berlomba memasukan bola ke dalam jaring atau keranjang yang terdapat pada gambar penyu dengan dilempar.

Tujuan permainan adalah untuk melatih kemampuan melempar bola kearah sasaran, mendorong anak untuk bisa melempar bola ke arah sasaran dan berkonsentrasi, dan menumbuhkan kesenangan anak dalam melakukan aktivitas gerak. Adapun indikator keberhasilan dalam melakukan permainan yaitu anak mau melemparkan bola ke arah gambar, dapat memasukan bola ke dalam keranjang, dan anak senang dalam melakukan aktivitas permainan.

Tabel 2. Perolehan Nilai Ketika Melakukan Permainan Lempar Kaleng

\begin{tabular}{lcccc}
\hline \multicolumn{1}{c}{ Aspek yang dinilai } & Jumlah nilai I & Jumlah nilai II & Mean I & Mean II \\
\hline Melemparkan bola & 392 & 466 & 2.61 & 3.11 \\
Melompat & 474 & 482 & 3.16 & 3.21 \\
Merangkak & 462 & 490 & 3.08 & 3.27 \\
Berjalan di atas garis & 488 & 523 & 3.25 & 3.49 \\
Menjatuhkan bambu & 382 & 421 & 2.55 & 2.81 \\
Kegembiraan & 474 & 498 & 3.16 & 3.32 \\
Jumlah & 2672 & 2880 & 2.97 & 3.2 \\
\hline
\end{tabular}


Jurnal Keolahragaan 7 (1), 2019 - 28

Uray Gustian, Eka Supriatna, Edi Purnomo

Tabel 3. Perolehan Nilai Ketika Melakukan Permainan Engklek

\begin{tabular}{lcccc}
\hline \multicolumn{1}{c}{ Aspek yang dinilai } & Jumlah nilai I & Jumlah nilai II & Mean I & Mean II \\
\hline Melakukan engklek & 467 & 472 & 3.11 & 3.15 \\
Kesesuaian engklek & 482 & 490 & 3.21 & 3.26 \\
Kegembiraan & 492 & 523 & 3.28 & 3.49 \\
Jumlah & 1441 & 1485 & 3.20 & 3.3 \\
\hline
\end{tabular}

Tabel 4. Perolehan Nilai Ketika Melakukan Permainan Lempar Telur Penyu

\begin{tabular}{lcccc}
\hline \multicolumn{1}{c}{ Aspek yang dinilai } & Jumlah nilai I & Jumlah nilai II & Mean I & Mean II \\
\hline Melemparkan bola & 481 & 490 & 3.21 & 3.27 \\
Memasukan bola ke target & 386 & 492 & 2.57 & 3.28 \\
Kegembiraan & 528 & 532 & 3.52 & 3.55 \\
Jumlah & 1395 & 1514 & 3.1 & 3.36 \\
\hline
\end{tabular}

Permainan dilakukan dengan guru menyiapkan peralatan yang dibutuhkan yaitu menyusun kayu, karton, dan jaring serta membuat garis batas untuk anak melempar. Kemudian guru membagi anak ke dalam 4 kelompok dengan jumlah anak disesuaikan dengan jumlah anak dalam tiap kelas. Sebelum memulai permainan guru menjelaskan cara melakukan permainan yaitu setiap kelompok akan berlomba untuk memasukan bola ke dalam jaring dengan cara dilempar oleh anak secara bergantian. Guru mengawasi anak yang sedang melakukan permainan dan pada akhir permainan guru menghitung bola yang berhasil dimasukan oleh anakanak. Kelompok yang paling banyak memasukan bola dinyatakan sebagai pemenang.

Hasil penelitian pada permainan lempar telur penyu yang disajikan pada Tabel 4 diperoleh hasil kemampuan anak melemparkan bola pada pertemuan I 481 (3.21) dan 490 (3.27) pertemuan II, kemampuan memasukan bola ke target pertemuan I 386 (2.57) dan 492 (3.28) pada pertemuan II, dan kegembiraan 528 (3.52) pada pertemuan I dan 532 (3.55) pada pertemuan II serta secara keseluruhan permainan engklek diperoleh hasil 1395 (3.1) pada pertemuan I dan 1514 (3.36) pertemuan II. Berdasarkan pencapaian hasil telah terjadi peningkatan pada kemampuan melemparkan bola, kemampuan memasukan bola ke target, kegembiraan, dan permainan engklek secara keseluruhan.

Berdasarkan penilaian unjuk kerja pada permainan lempar telur penyu telah terjadi peningkatan kategori pada kemampuan memasukan bola ke target yaitu dari mulai berkembang menjadi berkembang sesuai harapan. Untuk kemampuan melemparkan bola, kegembiraan, dan perolehan nilai secara keseluruhan belum terjadi peningkatan masih berada pada kategori berkembang sesuai harapan antara pertemuan I dan II. Hal ini menunjukan baik secara perolehan hasil dapat meningkatkan PL anak.

Sumpitan

Sumpitan merupakan olahraga tradisional masyarakat Suku Dayak yang ada di Kalimantan yang biasa dilakukan untuk berburu hewan. Dalam aktivitas Pembelajaran ini sumpitan dilakukan dalam bentuk permainan yang dilakukan dengan menyumpitkan kacang hijau menggunakan sedotan minuman. Anak akan menyumpit kearah target yang telah ditentukan. Adapun yang menjadi target adalah gambar hewan yang telah diberi lobang ditengahnya. Anak memasukan kacang hijau pada lobang dengan disumpitkan menggunakan sedotan. Target juga bisa diganti dengan botol air mineral $600 \mathrm{ml}$ yang telah kosong. Anak diminta untuk menjatuhkan botol air dengan cara menyumpitkan kacang hijau menggunakan sedotan minuman ke arah botol air. Jarak antara anak dengan target sekitar 1, 5 sampai 2 meter.

Tujuan sumpitan adalah untuk melatih kemampuan gerak manipulatif yaitu meniupkan kacang hijau, mendorong anak untuk memecahkan masalah sederhana dan mampu melakukan aktivitas meniupkan kacang hijau, dan menumbuhkan kesenangan anak dalam melakukan aktivitas gerak. Indikator keberhasilan anak dalam melakukan permainan sumpitan yaitu anak dapat menyumpitkan kacang hijau menggunakan sedotan minuman, dapat memasukan kacang hijau dengan disumpitkan ke arah target, dan anak senang dalam melakukan permainan sumpitan.

Permainan sumpitan dilakukan dengan guru menyiapkan peralatan yang akan dibutuhkan. Guru membagi anak ke dalam 4 sampai 5 kelompok dan membagikan sedotan dan kacang hijau kepada masing-masing anak. Guru menjelaskan cara melakukan permainan yaitu setiap anak 
secara bergantian menyumpitan kacang hijau dengan cara masukan kacang hijau ke dalam sedotan kemudian ditiupkan kearah lobang yang ada di gambar atau botol yang diletakan diatas kayu dengan jarak sekitar 1.5 sampai 2 meter. Kelompok yang paling banyak memasukan kacang hijau ke dalam lobang yang ada di gambar atau menjatuhkan botol air mineral terlebih dahulu dijadikan sebagai pemenang.

Perolehan hasil pada permainan sumpitan diperoleh hasil kemampuan meniupkan kacang hijau 402 (2.68) pada pertemuan I dan 462 (3.08) pertemuan II, kemampuan menjatuhkan botol pertemuan I 382 (2.55) dan 390 (2.6) pertemun II, kegembiraan 467 (3.11) pada pertemuan I dan 523 (3.49) pertemuan II, dan secara keseluruhan untuk permainan sumpitan diperoleh hasil 1251 (2.78) pada pertemuan I dan 1375 (3.06) pada pertemuan II. Berdasarkan pencapaian hasil belajar menunjukan telah terjadi peningkatan pada kemampuan meniupkan kacang hijau, menjatuhkan botol, kegembiraan, dan permainan sumpitan secara keseluruhan. Hal ini menunjukan permainan sumpitan dapat meningkatkan PL.

\section{Balap Balon}

Balap Balon merupakan permainan yang diadopsi dari permainan balap karung. Balap karung merupakan permainan tradisional yang biasa dimainkan oleh masyarakat dalam merayakan Hari Ulang Tahun (HUT) Kemerdekaan Republik Indonesia. Permainan balap karung dimainkan dengan cara anak-anak berlomba menuju garis finish dengan cara melompat menggunakan karung. Adapun dalam aktivitas pembelajaran untuk anak usia dini yang dimaksud permainan balap balon adalah permainan menuju garis finis dengan cara anak melompat melewati lingkaran yang telah disusun sebelumnya tanpa menggunakan balon yang diapit menggunakan tungkai. Permainan ini dilakukan secara estafet yang ditandai dengan setiap anak yang melakukan lompatan harus membawa tongkat kayu.

Tujuan permainan balap balon untuk melatih kemampuan gerak dasar yaitu melompat, mendorong anak untuk bisa melompat melewati lingkaran sampai garis finish, mendorong anak untuk memecahkan masalah sederhana, dan menumbuhkan kesenangan anak dalam melakukan aktivitas gerak. Indikator keberhasilan yaitu anak dapat melompat menuju garis finish, dapat melewati lingkaran dengan cara melompat, dan Anak gembira dalam melakukan.

Permainan balon balon dilakukan dengan cara guru membagi Anak ke dalam beberapa kelompok minimal tiga maksimal lima kelompok. Guru membagi anggota tiap kelompok menjadi 2 kelompok dengan satu kelompok berdiri di belakang garis start dan satu kelompok berdiri di belakang garis finish. Guru menjelaskan mengenai cara melakukan permainan yaitu anak anak berlomba membawa tongkat kayu secara estafet melompat melewati setiap lingkaran sampai menyetuh garis finis. Setelah menyampai garis finis anak yang melakukan akan menyerahkan tongkat tersebut kepada teman berikutnya yang akan melakukan lompatan. Kegiatan ini terus dilakukan sampai semua anak berhasil melakukan. Kelompok yang paling cepat dan benar menyelesaikan permainan dinyatakan sebagai pemenang. Guru melakukan pengamatan dan pengawasan serta menentukan kelompok mana yang dinyatakan sebagai pemenang.

Perolehan hasil Perolehan hasil pada permainan balap balon pada kemampuan mengapit bola menggunakan bola 434 (2.89) pada pertemuan I dan 488 (3.25) pertemuan II, melompat melewati garis pada pertemuan I 490 (3.27) dan pertemuan II 510 (3.4), kegembiraan pertemuan I 502 (3.35) dan pertemuan II 522 (3.48), dan secara keseluruhan diperoleh hasil 1426 (3.17) pada pertemuan I dan 1520 (3.38) pada pertemuan II. Berdasarkan pencapaian hasil tersebut menunjukan telah terjadi peningkatan perolehan hasil pada kemampuan mengapit balon menggunakan paha, melompat melewati garis, kegembiraan, dan perolehan hasil secara keseluruhan pada permainan balap balon. Hal ini menunjukan pada permainan balap balon telah terjadi peningkatan PL anak.

\section{Estafet Kelereng}

Permainan estafet kelereng merupakan permainan yang dilakukan dengan membawa kelereng menggunakan sendok yang diletakan di mulut. Permainan ini juga biasa dilakukan untuk merayakan HUT Kemerdekaan Republik Indonesia. Dalam aktivitas permbelajaran, permainan estafet kelereng yang akan digunakan adalah permainan lomba kelereng secara estafet yang mana kelereng diganti dengan bola tenis meja. 
Jurnal Keolahragaan 7 (1), 2019 - 30

Uray Gustian, Eka Supriatna, Edi Purnomo

Tabel 5. Perolehan Nilai Ketika Melakukan Permainan Sumpitan

\begin{tabular}{lcccc}
\hline \multicolumn{1}{c}{ Aspek yang dinilai } & Jumlah nilai I & Jumlah nilai II & Mean I & Mean II \\
\hline Meniupkan kacang hijau & 402 & 462 & 2.68 & 3.08 \\
Menjatuhkan botol & 382 & 390 & 2.55 & 2.6 \\
Kegembiraan & 467 & 523 & 3.11 & 3.49 \\
Jumlah & 1251 & 1375 & 2.78 & 3.06 \\
\hline
\end{tabular}

Tabel 6. Perolehan Nilai Ketika Melakukan Permainan Balap Balon

\begin{tabular}{lcccc}
\hline \multicolumn{1}{c}{ Aspek yang dinilai } & Jumlah nilai I & Jumlah nilai II & Mean I & Mean II \\
\hline Mengapit balon menggunakan paha & 434 & 488 & 2.89 & 3.25 \\
Melompat Melewati garis & 490 & 510 & 3.27 & 3.4 \\
Kegembiraan & 502 & 522 & 3.35 & 3.48 \\
Jumlah & 1426 & 1520 & 3.17 & 3.38 \\
\hline
\end{tabular}

Tabel 7. Perolehan Nilai Ketika Melakukan Permainan Estafet Kelereng

\begin{tabular}{lllll}
\hline \multicolumn{1}{c}{ Aspek yang dinilai } & Jumlah nilai I & Jumlah nilai II & Mean I & Mean II \\
\hline Membawa kelereng menuju finis & 464 & 488 & 3.09 & 3.25 \\
Menempatkan kelereng & 484 & 510 & 3.23 & 3.4 \\
Kegembiraan & 486 & 502 & 3.24 & 3.36 \\
Jumlah & 1434 & 1500 & 3.19 & 3.33 \\
\hline
\end{tabular}

Tujuan permainan estafet kelereng untuk melatih kemampuan keseimbangan anak, mendorong anak untuk dapat membawa bola pingpong menggunakan sendok, dan menumbuhkan kesenangan anak dalam melakukan aktivitas gerak. Indikator keberhasilan anak dalam melakukan permainan estafet kelereng yaitu anak dapat membawa bola pingpong tanpa jatuh, dapat melewati garis finish, dan Anak gembira dalam melakukan aktivitas permainan.

Cara melakukan permainan estafet kelereng guru membagi Anak ke dalam beberapa kelompok minimal tiga maksimal lima kelompok. Guru membagi anggota tiap kelompok menjadi 2 kelompok dengan satu kelompok berdiri dibelakang garis start dan satu kelompok berdiri di belakang garis finish. Guru menjelaskan mengenai cara melakukan permainan yaitu anak anak berlomba membawa tongkat kayu secara estafet melompat melewati setiap lingkaran sampai menyetuh garis finis. Setelah menyampai garis finis anak yang melakukan menyerahkan tongkat tersebut kepada teman berikutnya yang akan melakukan lompatan. Kegiatan ini terus dilakukan sampai semua anak berhasil melakukan. Kelompok yang paling cepat dan benar menyelesaikan permainan dinyatakan sebagai pemenang. Guru mengamati dan mengawasi serta menentukan kelompok mana yang dinyatakan sebagai pemenang.

Perolehan hasil pada permainan estafet kelereng terhadap kemampuan membawa kelereng menuju finis 464 (3.09) pada pertemuan I dan 488 (3.25) pada pertemuan II, kemampuan menempatkan kelereng 484 (3.23) pada pertemu- an I dan 510 (3.4) pada pertemuan II, kegembiraan 486 (3.24) pada pertemuan I dan 502 (3.36) pada pertemuan ke II, dan secara keseluruhan perolehan hasil pada permaian estafet kelereng 1434 (3.19) pada pertemuan ke I dan 1500 (3.33) pada pertemuan II. Hasil ini menunjukan bahwa telah terjadi peningkatan perolehan hasil pada kemampuan membawa kelereng menuju finish, menempatkan kelereng, kegembiraan, dan secara keseluruhan pada permainan estafet kelereng. Hasil ini menunjukan permainan estafet kelereng telah dapat meningkatkan PL anak.

Bakiak

Permainan bakiak adalah permainan tradisional dari salah satu daerah yang ada di Indonesia, permainan ini cocok dimainkan untuk Anak taman kanak-kanak dengan permainan ini anak-anak akan dibagi ke dalam beberapa kelompok dan 1 kelompok terdapat 3-4 anak. Dalam permainan ini Anak dapat melatih kekompakkan dalam tim dan tidak mementingkan ego masingmasing. Untuk menarik minat Anak taman kanak-kanak permainan ini dibuat berbasis kompetisi agar anak-anak lebih antusias dalam bermain dan juga ini bisa melatih gerak motorik anak tersebut.

Tujuan permainan bakiak yaitu mengembangkan keseimbangan, menumbuhkan rasa senang saat bermain di lapangan, dan menumbuhkan rasa saling percaya terhadap teman (kerja sama). Indikator keberhasilan yaitu anak dapat berjalan melewati garis finish menggunakan bakiak, gembira dalam melakukan permainan, dan dapat bersama-sama menggerakan bakiak. 
Jurnal Keolahragaan 7 (1), 2019 - 31

Uray Gustian, Eka Supriatna, Edi Purnomo

Tabel 8. Perolehan Nilai Ketika Melakukan Permainan Bakiak

\begin{tabular}{lllll}
\hline \multicolumn{1}{c}{ Aspek yang dinilai } & \multicolumn{1}{c}{ Jumlah nilai I } & Jumlah nilai II & Mean I & Mean II \\
\hline Melangkah Secara Bersamaan & 364 & 388 & 2.43 & 2.59 \\
Melewati Garis Finis & 384 & 410 & 2.56 & 2.73 \\
Kegembiraan & 476 & 524 & 3.17 & 3.49 \\
Jumlah & 1224 & 1322 & 2.72 & 2.94 \\
\hline
\end{tabular}

Tabel 9. Rekapitulasi Perolehan Hasil Pada Ketujuh Permainan Tradisional Yang Dimodifikasi

\begin{tabular}{lllll}
\hline \multicolumn{1}{c}{ Jenis permainan tradisional } & Hasil pertemuan I & Hasil pertemuan I & Mean I & Mean II \\
\hline Lempar Kaleng & 2672 & 2880 & 2.97 & 3.2 \\
Engklek & 1441 & 1485 & 3.20 & 3.3 \\
Lempar Telur Penyu & 1395 & 1514 & 3.1 & 3.36 \\
Sumpitan & 1251 & 1375 & 2.78 & 3.06 \\
Balap Balon & 1426 & 1520 & 3.17 & 3.38 \\
Estafet Kelereng & 1434 & 1500 & 3.19 & 3.33 \\
Bakiak & 1224 & 1322 & 2.72 & 2.94 \\
Jumlah & 10843 & 11596 & 3.02 & 3.22 \\
\hline
\end{tabular}

Cara melakukan permainan bakiak yaitu anak dibagi ke dalam beberapa kelompok (jumlah kelompok disesuaikan dengan jumlah Anak yang ada), Masing-masing kelompok yang ada dibagi kedalam grup A, B, C, Masing-masing grup berlomba untuk sampai ke garis finish yang sudah ditentukan. Setelah dari masing-masing grup sudah dapat juaranya maka setiap perwakilan grup akan berlomba lagi untuk penentuan juaranya.

Perolehan hasil pada permainan bakiak terhadap kemampuan melangkah bersamaan diperoleh hasil 364 (2.43) pada pertemuan I dan 388 (2.59) pada pertemuan II, kemampuan melewati garis finish 384 (2.56) pada pertemuan I dan 410 (2.73) pada pertemuan II, kegembiraan 476 (3.17) pada pertemuan I dan 524 (3.49) pada pertemuan II, dan secara keseluruhan permainan bakiak secara keseluruhan diperoleh hasil 1224 (2.72) pada pertemuan I dan 1322 (2.94) pada pertemuan II. Hasil ini menunjukan telah terjadi peningkatan perolehan hasil pada kemampuan melangkah secara bersamaan, melewati garis finis, kegembiraan, dan secara keseluruhan pada permainan bakiak. Berdasarkan hasil tersebut permainan bakiak dapat meningkatkan PL anak.

Berdasarkan hasil rekapitulasi perolehan hasil secara keseluruhan permainan tradisional sebagaimana yang dijabarkan Tabel 9 pertemuan pertama diperoleh hasil 10843 (3.02) dan 11596 (3.22) pada pertemuan II. Hasil tersebut menunjukan bahwa telah terjadi peningkatan PL anak TK.

Berdasarkan hasil penelitian terhadap tujuh permainan tradisional yang dimodifikasi secara keseluruhan diperoleh hasil bahwa permainan tradisional dapat meningkatkan PL anak
TK. Peningkatan terjadi disebabkan permainan tradisional memberikan kesempatan kepada anak untuk bermain secara berkelompok, peralatan yang digunakan sederhana, mengandung sarat nilai budaya, dilakukan dengan rasa senang tanpa adanya tekanan (Kurniati, 2016).

Selain itu juga, permainan tradisional merupakan sarana dalam mengembangkan aspek perkembangan dasar anak, seperti: pisik-mitorik, kognitif, sosial-emosional, dan bahasa (Khasanah, Prasetyo, \& Rakhmawati, 2011), menanamkan sikap hidup dan keterampilan seperti nilai kerjasama, kebersamaan, kedisiplinan, kejujuran, dan musyawarah mufakat karena ada aturan yang harus dipenuhi oleh anak sehingga membangun karakter anak (Nur, 2013, pp. 9192). Dalam permainan tradisional banyak melibatkan gerak tubuh, melibatkan lagu atau suara sebagai media, melibatkan alat main. Akan peningkatan yang terjadi hanya sebesar 753 point dan secara rata-rata perbedaan sebesar 0.21. Peningkatan ini tentunya masih relatif rendah. Hal ini dikarena implementasi permainan tradisional yang dimodifikasi pada pembelajaran anak TK hanya dilakukan sebanyak dua kali percobaan atau hanya empat kali pertemuan. Hasil ini tentunya belum memberikan dampak yang signifikan terhadap perkembangan PL anak TK. Permainan tradisional bisa menjadi media yang baik dalam mengembangkan PL anak.

\section{SIMPULAN}

Permainan tradisional yang dimodifikasi telah terbukti efektif dalam mengembangkan PL anak TK. Hal ini menunjukan PL anak TK dapat distimulus melalui permainan tradisional karena melalui permainan tradisional anak lebih aktif 
dalam melakukan aktivitas gerak dan memberikan kesempatan pada anak untuk bermain secara berkelompok. dan menggunakan media permainan yang membuat anak tertarik, mau, dan senang dalam melakukannya. Selain itu juga, permainan tradisional merupakan aktivitas yang mudah untuk dilakukan anak ketika berada di rumah. Langkah selanjutnya yang perlu untuk dilakukan adalah mengembangkan berbagai macam permainan yang menarik dan interaktif bagi anak sehingga lebih merangsang anak untuk selalu aktif melakukan gerak, memiliki kepercayaan diri, motivasi, dan memiliki keterampilan gerak yang baik.

\section{DAFTAR PUSTAKA}

Butler, J., \& Griffin, L. (2010). More teaching games for understanding: Moving globally. Human Kinetics.

Daggett, S. (2010). Physical education and literacy: The odd couple or a match made in heaven. Educator's Voice, 3, 42-49.

Darminiasih, N. N., Marhaeni, A. A. I. N., \& Sutama, I. M. (2014). Penggunaan metode bermain permainan tradisional dalam upaya meningkatkan kemampuan berbahasa dan sosial emosional anak kelompok B TK Sebana Sari. PENDASI: Jurnal Pendidikan Dasar Indonesia, 4(1). Retrieved from http://oldpasca.undiksha.ac.id/ejournal/index.php/jurnal_pendas/article/vi ew/1152

Direktorat Pembinaan Pendidikan Anak Usia Dini. (2011). Petunjuk teknis penyelenggaraan taman kanak-kanak. Jakarta: Direktorat Jenderal Pendidikan Anak Usia Dini, Formal dan Non-Formal, Kementerian Pendidikan Nasional.

Fedewa, A. L., \& Ahn, S. (2011). The effects of physical activity and physical fitness on children's achievement and cognitive outcomes: a meta-analysis. Research Quarterly for Exercise and Sportxercise and Sport, 82(3), 521-535. https://doi.org/10.1080/02701367.2011.10 599785

Gallahue, D. L., \& Ozmun, J. C. (2006). Understanding motor development: Infants, children, adolescents, adults. McGraw-Hill Humanities, Social Sciences \& World Languages.

Ginsburg, K. R. (2007). The importance of play in promoting healthy child development and maintaining strong parent-child bonds. Pediatrics, 119(1), 182-191. https://doi.org/10.1542/peds.2006-2697

Gustian, U., \& Hidasari, F. P. (2017). The model of games to develop fundamental movement. In The 1st Yogyakarta International Seminar On Healt, Physical Educaton, and Sport Science (1st YISHPESS) (pp. 481-488). Yogyakarta: Faculty of Sport Science, Universitas Negeri Yogyakarta.

Gustian, U., \& Tomoliyus, T. (2015). Pengembangan model pembelajaran integratif berbasis aktivitas jasmani untuk anak taman kanak-kanak. Jurnal Keolahragaan, 3(2), 241-251. https://doi.org/10.21831/jk.v3i2.6262

Haapala, E. A. (2013). Cardiorespiratory fitness and motor skills in relation to cognition and academic performance in children-a review. Journal of Human Kinetics, 36(1), 55-68. https://doi.org/10.2478/hukin2013-0006

Higgs, C., Balyi, I., Way, R., Cardinal, C., Norris, S., \& Bluechardt, M. (2008). Developing physical literacy: A guide for parents of children ages 0 to 12 . Vancouver, BC: Canadian Sports Centres.

Khasanah, I., Prasetyo, A., \& Rakhmawati, E. (2011). Permainan tradisional sebagai media stimulasi aspek perkembangan anak usia dini. PAUDIA: Jurnal Penelitian Dalam Bidang Pendidikan Anak Usia Dini, $\quad$ 1(1). https://doi.org/10.26877/paudia.v1i1.261

Kirk, M. A., \& Rhodes, R. E. (2011). Motor skill interventions to improve fundamental movement skills of preschoolers with developmental delay. Adapted Physical Activity Quarterly, 28(3), 210-232. https://doi.org/10.1123/apaq.28.3.210

Kohl, H. W., Craig, C. L., Lambert, E. V., Inoue, S., Alkandari, J. R., Leetongin, G., ... Lancet Physical Activity Series Working Group. (2012). The pandemic of physical inactivity: global action for public health. The Lancet, 380(9838), 294-305. https://doi.org/10.1016/S01406736(12)60898-8

Kovar, S. K. (2004). Elementary classroom teachers as movement educators. McGraw-Hill Companies. 
Kurniati, E. (2016). Permainan tradisional dan perannya dalam mengembangkan keterampilan sosial anak. Kencana.

Liu, M., Karp, G. G., \& Davis, D. (2010). Teaching learning-related social skills in kindergarten physical education. Journal of Physical Education, Recreation \& Dance, 81(6), 38-44. https://doi.org/10.1080/07303084.2010.10 598490

Nur, H. (2013). Membangun karakter anak melalui permainan anak tradisional. Jurnal Pendidikan Karakter, 3(1), 87-94. https://doi.org/10.21831/jpk.v0i1.1290

Pagani, L. S., Fitzpatrick, C., \& Barnett, T. A. (2013). Early childhood television viewing and kindergarten entry readiness. Pediatric Research, 74(3), 350.

Permuseuman, I. D. (1998). Permainan tradisional Indonesia. Departemen Pendidikan dan Kebudayaan, Direktorat Jenderal Kebudayaan, Direktorat Permuseuman.

Robinson, L. E., \& Goodway, J. D. (2009). Instructional climates in preschool children who are at-risk. Part I: Objectcontrol skill development. Research
Quarterly for Exercise and Sport, 80(3), 533-542.

https://doi.org/10.1080/02701367.2009.10 599591

Taylor, R. W., Williams, S. M., Farmer, V. L., \& Taylor, B. J. (2013). Changes in physical activity over time in young children: a longitudinal study using accelerometers. PLOS ONE, 8(11), e81567. https://doi.org/10.1371/journal.pone.0081 567

Williams, H. G., Pfeiffer, K. A., O'neill, J. R., Dowda, M., McIver, K. L., Brown, W. H., \& Pate, R. R. (2008). Motor skill performance and physical activity in preschool children. Obesity, 16(6), 14211426. https://doi.org/10.1038/oby.2008.214

World Health Organization. (2011). WHO Global recommendations on physical activity for health. Geneva: World Health Organization, United Nations.

Yudiwinata, H. P., \& Handoyo, P. (2014). Permainan tradisional dalam budaya dan perkembangan anak. Paradigma, 2(3). Retrieved from http://jurnalmahasiswa.unesa.ac.id/index. php/paradigma/article/view/9088 